\title{
Assessment of Fertilizer Management Strategies Aiming to Increase Nitrogen Use Efficiency of Wheat Grown Under Conservation Agriculture
}

\author{
Jesús Santillano-Cázares ${ }^{1}$ [D, Fidel Núñez-Ramírez ${ }^{1}$, Cristina Ruíz-Alvarado ${ }^{1}$, \\ María Elena Cárdenas-Castañeda ${ }^{2}$ and Iván Ortiz-Monasterio ${ }^{2, *}$ \\ 1 Instituto de Ciencias Agrícolas, Universidad Autónoma de Baja California, Carretera a Delta s/n, \\ Ejido Nuevo Leon, Mexicali, Baja California C. P. 21705, Mexico; jsantillano@uabc.edu.mx (J.S.-C.); \\ fidel.nunez@uabc.edu.mx (F.N.-R.); mariacristina@uabc.edu.mx (C.R.-A.) \\ 2 Centro Internacional de Mejoramiento de Maíz y Trigo (CIMMYT), Km. 45, Carretera Mexico-Veracruz, \\ El Batan, Texcoco Edo. de Mexico C. P. 56237, Mexico; m.cardenas@cgiar.org \\ * Correspondence: i.ortiz-monasterio@cgiar.org; Tel.: +52-55-5804-2004.
}

Received: 14 November 2018; Accepted: 11 December 2018; Published: 16 December 2018

\begin{abstract}
Sustainable crop production systems can be attained by using inputs efficiently and nitrogen use efficiency (NUE) parameters are indirect measurements of sustainability of production systems. The objective of this study was to investigate the effect of selected nitrogen $(\mathrm{N})$ management treatments on wheat yields, grain and straw $\mathrm{N}$ concentration, and NUE parameters, under conservation agriculture (CA). The present study was conducted at the International Maize and Wheat Improvement Center (CIMMYT), in northwest, Mexico. Seventeen treatments were tested which included urea sources, timing, and methods of fertilizer application. Orthogonal contrasts were used to compare groups of treatments and correlation and regression analyses were used to look at the relationships between wheat yields and NUE parameters. Contrasts run to compare wheat yields or agronomic efficiency of $\mathrm{N}\left(\mathrm{AE}_{\mathrm{N}}\right)$ performed similarly. Sources of urea or timing of fertilizer application had a significant effect on yields or $\mathrm{AE}_{\mathrm{N}}(p>0.050)$. However, methods of application resulted in a highly significant $(p<0.0001)$ difference on wheat yields and agronomic efficiency of $\mathrm{N}$. NUE parameters recorded in this study were average but the productivity associated to NUE levels was high. Results in this study indicate that wheat grew under non-critically limiting $\mathrm{N}$ supply levels, suggesting that $\mathrm{N}$ mineralization and reduced $\mathrm{N}$ losses from the soil under $\mathrm{CA}$ contributed to this favorable nutritional condition, thus minimizing the importance of $\mathrm{N}$ management practices under stable, mature CA systems.
\end{abstract}

Keywords: conservation agriculture; NUE; nitrogen recovery efficiency; nitrogen physiological recovery; wheat yields; Agrotain ${ }^{\circledR}$ urea

\section{Introduction}

One of the most limiting inputs in crop production and quality is nitrogen (N) [1]. Ironically, $\mathrm{N}$ fertilizer that is not used to support crop production has the potential to cause a series of environmental issues such as eutrophication on water bodies, acid rain, $\mathrm{N}$ saturation in natural environments, and global warming [2,3]. Losses of $\mathrm{N}$ from agricultural systems negatively impact the environment as a result of poor $\mathrm{N}$ fertilizer management practices. This, in turn, results in low profitability to farmers $[4,5]$. Sustainable crop production systems, i.e., systems that take into account people's wellbeing, farmer's economy, and that are environmentally safe, can be attained by using inputs efficiently. Nitrogen use efficiency (NUE) and NUE components are indirect measurements of 
the sustainability of production systems [6-8], therefore, a strong emphasis is being placed on NUE in wheat production systems [9-11]. In this paper NUE is defined as grain yield per unit of available $\mathrm{N}$ in the soil [12-14]. NUE components, $\mathrm{N}$ uptake efficiency (NUpE), and N utilization efficiency (NUtE) have been typically used for characterizing newly developed cereal genotypes [14-16]. However, for testing the $\mathrm{N}$ efficiency of agronomic practices other NUE and associated components have been proposed. Dobermann (2005) [17] and Ladha et al. (2005) [18] recommend measuring the agronomic efficiency of applied $N\left(\mathrm{AE}_{\mathrm{N}}\right)$, crop recovery efficiency of applied $\mathrm{N}\left(\mathrm{RE}_{\mathrm{N}}\right)$, and physiological efficiency of applied $\mathrm{N}\left(\mathrm{PE}_{\mathrm{N}}\right)$. $\mathrm{AE}_{\mathrm{N}}$ is the product of the recovered $\mathrm{N}$ by the plant, multiplied by the efficiency with which this $\mathrm{N}$ is converted into the crop's part of economic interest (grain, for cereals). According with Dobermann (2005) [17] and Hawkesford (2017) [13], the $\mathrm{AE}_{\mathrm{N}}$ can be improved by crop management practices such as amount, timing, placement, and $\mathrm{N}$ source that can influence $\mathrm{RE}_{\mathrm{N}}$, $P E_{N}$, or both. $R E_{N}$ relays on the efficacy with which applied $N$ is released for crop uptake, and can vary depending on amount, timing, placement and $\mathrm{N}$ sources. On the other hand, $\mathrm{PE}_{\mathrm{N}}$ measures the ability of a plant to convert the absorbed $N$ into the product of interest; $P E_{N}$, as well as $R E_{N}$, is also dependent on crop management factors but particularly on reproductive stages. According to Malhi et al. (2001) [19], an effective N management program must take into account four variables: Rate, source, timing, and placement of fertilizers. Yadav et al. (2017) [8] proposed site specific N management; integrated $\mathrm{N}$ management, i.e., taking into account indigenous $\mathrm{N}$ sources like crop residues, manure, biological $\mathrm{N}$ fixation, in addition to synthetic fertilizers; enhanced use of efficient sources; improved methods of application; adoption of conservation agriculture (CA); the use of $\mathrm{N}$-efficient genetically improved varieties; and precision farming. Because of the need to increase the sustainability of modern crop production systems, it's important to better understand the relationship between NUE and fertilizer management practices for wheat produced under CA systems. Published literature about NUE for irrigated wheat under CA is very scarce. The objective of the present study was to investigate the effect of selected treatments that included $\mathrm{N}$ (urea) sources, timing, and methods of application, on wheat yield, grain and straw $\mathrm{N}$ concentration, and NUE, under a CA system.

\section{Materials and Methods}

\subsection{Site Description}

The present study was conducted at the International Maize and Wheat Improvement Center (CIMMYT) agricultural experimental station, in the Yaqui valley, near Ciudad Obregon, Sonora, Mexico. The study consisted of five wheat growing cycles, from 2009-2010 to 2013-2014. The field within the station is located at $27^{\circ} 23^{\prime} 11.9^{\prime \prime} \mathrm{N}, 109^{\circ} 55^{\prime} 33^{\prime \prime} \mathrm{W}$. Historical temperatures during the wheat growing season are $9.8^{\circ} \mathrm{C}$ and $27.1^{\circ} \mathrm{C}$ for night and daytime, respectively. Soils in the area are predominantly vertisols; which are characterized by being clayey, have deep, wide cracks when they dry, and have slickensides within $100 \mathrm{~cm}$ of the mineral soil surface. The weather occurring during the crop growing cycles was recorded at a weather station located within the experimental station (Figure 1). 

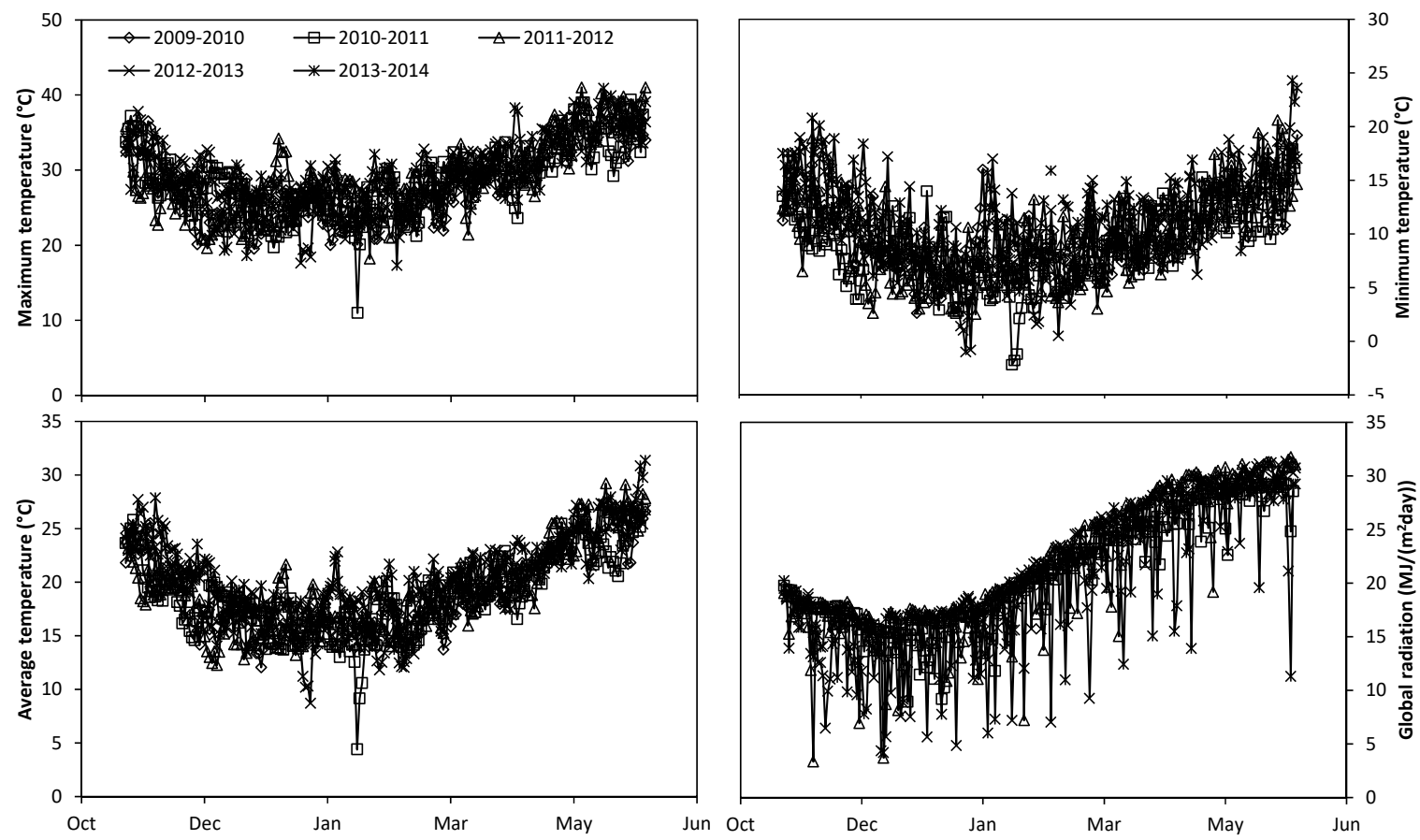

Figure 1. Maximum, minimum, average temperatures, and radiation occurring during five wheat growing cycles (2009-2010 to 2013-2014) at the International Maize and Wheat Improvement Center (CIMMYT), in the Yaqui valley, near Ciudad Obregon, Sonora, Mexico.

\subsection{Crop Management}

Planting dates over the five growing cycles ranged from the 23 of November to 11 of December. The wheat (Triticum Aestivum L.) varieties that were planted were Tacupeto F-2001 in cycle 2009-2010 and CIRNO C-2008 in the following four cycles. Seeding rates ranged between $100 \mathrm{~kg} \mathrm{ha}^{-1}$, in the first two cycles, to $120 \mathrm{~kg} \mathrm{ha}^{-1}$, in the last three cycles. In all five cycles furrow irrigation was applied when $50 \%$ available water had been depleted on the $60 \mathrm{~cm}$ in the soil profile. Seeding occurred after soil moisture allowed agricultural machinery traffic after applying a pre-plant irrigation. Four additional irrigations were applied during the growing cycle. Pre-plant phosphorus fertilizer was applied at a rate of $52 \mathrm{~kg} \mathrm{ha}^{-1}$ of $\mathrm{P}_{2} \mathrm{O}_{5}$ as mono-ammonium phosphate (11-52-00), during the first two cycles, and $46 \mathrm{~kg} \mathrm{ha}^{-1}$ of $\mathrm{P}_{2} \mathrm{O}_{5}$ as triple super phosphate (00-46-00), during the last three cycles. The experiments were established under conservation agriculture during all five cycles, leaving all residues on the soil surface, only reforming beds, planting and fertilizing with disks on top of beds. The experimental area had been under conservation agriculture at least for four years before the establishment of these experiments. Chemical and mechanical control of weeds was applied, as well as standard practices for pest and insect control was employed. Herbicides and pesticides utilized throughout the duration of the study, rates and dates of application are shown in Table 1. 
Table 1. Active ingredients, commercial names, rates and dates of application of herbicides and pesticides in experiments conducted at the International Maize and Wheat Improvement Center (CIMMYT), in the Yaqui valley, near Ciudad Obregon, Sonora, Mexico.

\begin{tabular}{|c|c|c|}
\hline Herbicides & Insecticides & Fungicides \\
\hline & 2009-2010 & \\
\hline $\begin{array}{l}\text { Pinoxaden (Axial®) } 600 \mathrm{~mL} \mathrm{ha}^{-1} \\
\left.\text { Methylated rapeseed oil (Adigor }{ }^{\circledR}\right) 500 \mathrm{~mL} \mathrm{~L}^{-1} \text { of water } \\
4 \text { January } 2010\end{array}$ & & $\begin{array}{l}\text { Tebuconazole (Folicur®) } 500 \mathrm{~mL} \mathrm{ha}^{-1} \\
10 \text { March } 10\end{array}$ \\
\hline
\end{tabular}

4 January 2010

Pinoxaden (Axial®) $1 \mathrm{~L} \mathrm{ha}^{-1}$
Methylated rapeseed oil (Adigor®) $1.5 \mathrm{~L} \mathrm{ha}^{-1}$

2010-2011

Betacyflutrin + Imidacloroprid (Muralla max®) $450 \mathrm{~mL} \mathrm{ha}^{-1}$

3 January 2011

28 January 2011

2011-2012

Fluroxypyr 1-Methylheptyl Ester (Starane $\left.{ }^{\circledR}\right) 300 \mathrm{~mL} \mathrm{ha}^{-1}$

2011-2012

Bromoxynil (Buctril $\left.{ }^{\circ}\right) 1 \mathrm{~L} \mathrm{ha}^{-1}$

15 December 2011

Pinoxaden (Axial®) $500 \mathrm{~mL} \mathrm{ha}^{-1}$

Methylated rapeseed oil (Adigor $\AA$ ) $500 \mathrm{~mL} \mathrm{~L}^{-1}$ of water

20 December 2011

Pinoxaden (Axial®) $1 \mathrm{~L} \mathrm{ha}^{-1}$

3 January 2013

\author{
2013-2014
}

Fluroxypyr 1-Methylheptyl Ester (Starane $\left.{ }^{\circledR}\right) 400 \mathrm{~mL} \mathrm{ha}^{-1}$

Octanoic acid ester of bromoxynil (Broclean $\left.{ }^{\circledR}\right) 2 \mathrm{~L} \mathrm{ha}^{-1}$

Bifenthrin (165), Imidacloprid (Allectus $\left.{ }^{\circledR}\right) 200 \mathrm{~mL} \mathrm{ha}^{-1}$

3 January 2014

29 January 2014

Tebuconazole (Folicur $\left.{ }^{\circledR}\right) 800 \mathrm{~mL} \mathrm{ha}^{-1}$

9 Febuary 2012

Tebuconazole (Folicur $\left.{ }^{\circledR}\right) 800 \mathrm{~mL} \mathrm{ha}^{-1}$

6 March 2012 


\subsection{Treatments Description}

Seventeen treatments were tested (Table 2). Except for the control that received only the pre-plant phosphorus fertilizer application, all treatments received a total of $150 \mathrm{~kg} \mathrm{~N} \mathrm{ha}^{-1}$. Treatments included combinations of $\mathrm{N}$ sources (urea or NBPT-urea $\left(\right.$ Agrotain $\left.^{\mathrm{TM}}\right)$ ); timings of fertilizer application [(once at planting, splitting $50 \mathrm{~kg} \mathrm{~N} \mathrm{ha}^{-1}$ at planting $+100 \mathrm{~kg} \mathrm{~N} \mathrm{ha}^{-1}$ before first post-plant irrigation (by the onset of stem elongation), or $100 \mathrm{~kg} \mathrm{~N}$ ha $^{-1}$ at planting $+50 \mathrm{~kg} \mathrm{~N} \mathrm{ha}^{-1}$ before first post-plant irrigation (by the onset of stem elongation)]; and methods of fertilizer application [top-dress (or broadcast), incorporated at furrows, or incorporated at beds]. The plots received the same treatment every cycle and consisted on four $10 \mathrm{~m}$ long beds, with a separation of $80 \mathrm{~cm}$, with two rows of wheat on top. Incorporated $\mathrm{N}$ fertilizer applications were made with minimum tillage equipment and placed about 5 $\mathrm{cm}$ into the soil, below the residues.

Table 2. N management practices that included treatments composed of urea sources, timing, and methods of fertilizer application at the International Maize and Wheat Improvement Center (CIMMYT), in the Yaqui valley, near Ciudad Obregon, Sonora, Mexico.

\begin{tabular}{|c|c|c|c|c|}
\hline \multirow[b]{2}{*}{ Treatment } & \multirow{2}{*}{$\begin{array}{l}\text { N Rate } \\
\left(\mathrm{kg} \mathrm{ha}^{-1}\right)\end{array}$} & \multirow[b]{2}{*}{ Source of $\mathbf{N}$} & \multicolumn{2}{|c|}{ Variables Affecting Nitrogen Use Efficiency } \\
\hline & & & Timing of Application & $\begin{array}{l}\text { Metod of Fertilizer } \\
\text { Application }\end{array}$ \\
\hline 1 & 0 & Not applicable & Not applicable & Not applicable \\
\hline 2 & 150 & Urea & At planting & Top-dress \\
\hline 3 & 150 & Urea & At planting & Incorporadted at furrows \\
\hline 4 & 150 & Urea & At planting & Incorporadted at beds \\
\hline 5 & 150 & Urea & 50 at planting +100 before first post-plant irrigation & Top-dress \\
\hline 6 & 150 & Urea & 50 at planting +100 before first post-plant irrigation & Incorporadted at furrows \\
\hline 7 & 150 & Urea & 50 at planting +100 before first post-plant irrigation & Incorporadted at beds \\
\hline 8 & 150 & Urea & 100 at planting +50 before first post-plant irrigation & Incorporadted at furrows \\
\hline 9 & 150 & Urea & 100 at planting +50 before first post-plant irrigation & Incorporadted at beds \\
\hline 10 & 150 & NBPT-urea & At planting & Top-dress \\
\hline 11 & 150 & NBPT-urea & At planting & Incorporadted at furrows \\
\hline 12 & 150 & NBPT-urea & At planting & Incorporadted at beds \\
\hline 13 & 150 & NBPT-urea & 50 at planting +100 before first post-plant irrigation & Top-dress \\
\hline 14 & 150 & NBPT-urea & 50 at planting +100 before first post-plant irrigation & Incorporadted at furrows \\
\hline 15 & 150 & NBPT-urea & 50 at planting +100 before first post-plant irrigation & Incorporadted at beds \\
\hline 16 & 150 & NBPT-urea & 100 at planting +50 before first post-plant irrigation & Incorporadted at furrows \\
\hline 17 & 150 & NBPT-urea & 100 at planting +50 before first post-plant irrigation & Incorporadted at beds \\
\hline
\end{tabular}

\subsection{Response Variables}

Response variables were; grain yield, wheat grain and straw $\mathrm{N}$ concentration; agronomic efficiency of $\mathrm{N}\left(\mathrm{AE} \mathrm{E}_{\mathrm{N}}\right), \mathrm{N}$ recovery efficiency $\left(\mathrm{RE}_{\mathrm{N}}\right)$, and $\mathrm{N}$ physiological efficiency $\left(\mathrm{PE}_{\mathrm{N}}\right)$. Grain was harvested at or after physiological maturity and adjusted to $12 \%$ moisture. Grain and straw N concentration was determined during the first four cycles and were estimated by oven drying samples at $70{ }^{\circ} \mathrm{C}$ for $48 \mathrm{~h}$, ground with rotor mill to pass a $2 \mathrm{~mm}$ sieve for straw and $0.5 \mathrm{~mm}$ sieve for grain. Nitrogen content was determined by taking $0.25 \mathrm{~g}$ grain flour and $0.50 \mathrm{~g}$ for straw by micro-Kjeldahl method. NUE and NUE components were computed as described by Dobermann (2005) [17] and by Ladha et al. (2005) [18]: $\mathrm{AE}_{\mathrm{N}}=$ (grain yield from fertilized plots - grain yield from unfertilized plots) $/ \mathrm{N}$ fertilizer rate from fertilized plots; $\mathrm{RE}_{\mathrm{N}}=$ (total $\mathrm{N}$ in aboveground plant biomass from fertilized plots - total $\mathrm{N}$ aboveground plant biomass from unfertilized plots)/N fertilizer rate from fertilized plots; and $\mathrm{PE}_{\mathrm{N}}=$ grain yield from fertilized plots - grain yield from unfertilized plots)/(total $\mathrm{N}$ in aboveground plant biomass from fertilized plots - total $\mathrm{N}$ aboveground plant biomass from unfertilized plots). The units for $\mathrm{AE}_{\mathrm{N}}, \mathrm{RE}_{\mathrm{N}}$, and $\mathrm{PE}_{\mathrm{N}}$ are: $\mathrm{kg}$ grain $\mathrm{kg}^{-1} \mathrm{~N}, \mathrm{~kg} \mathrm{~N}$ in total biomass $\mathrm{kg}^{-1} \mathrm{~N}$, and $\mathrm{kg}_{\text {grain }} \mathrm{kg}^{-1} \mathrm{~N}$, respectively. Variables $R E_{N}$ and $P E_{N}$ were computed for four cycles, from 2009-2010 to 2012-2013, since grain and straw $\mathrm{N}$ concentration were determined only during these cycles; while $\mathrm{AE}_{\mathrm{N}}$ was computed for all five cycles, since this variable do not require grain or straw $\mathrm{N}$ concentration data for its computation. 


\subsection{Experimental Design and Analyses}

Treatments were arranged on a completely randomized block design. Statistical analyses were made by analyses of variance first, to examine the significance of the interaction cycles $\times$ treatment, and secondly, orthogonal contrasts were performed on pooled data from cycles where this interaction was non-significant. A total of 17 contrasts were performed for each response variable (Table 3). From all contrasts performed, contrasts 1,10, and 14 are of key relevance, since they compare the overall effects of sources, timing, and methods of fertilizer application, respectively. The rest of the contrasts, however, were planned to provide details for a better understanding about these overall comparisons. Proc GLM, statement: CONTRAST was used. Additionally, correlation and regression analyses were performed on yields, $\mathrm{AE}_{\mathrm{N}}$ and $\mathrm{AE}_{\mathrm{N}}$ components $\mathrm{RE}_{\mathrm{N}}$, and $\mathrm{PE}_{\mathrm{N}}$, using Proc Corr and Proc Reg, $\mathrm{SAS}$, version 9.0 was used (SAS Institute, Cary, CA, USA).

Table 3. Selected contrasts to compare the effects on wheat yield, grain and straw nitrogen concentration, agronomic efficiency of $\mathrm{N}\left(\mathrm{AE}_{\mathrm{N}}\right), \mathrm{N}$ recovery efficiency $\left(\mathrm{RE}_{\mathrm{N}}\right)$, and $\mathrm{N}$ physiological efficiency $\left(\mathrm{PE}_{\mathrm{N}}\right)$, as influenced by selected treatments composed of urea sources, timing and methods of fertilizer application at the International Maize and Wheat Improvement Center (CIMMYT), in the Yaqui valley, near Ciudad Obregon, Sonora, Mexico.

\begin{tabular}{cl}
\hline & \multicolumn{1}{c}{ Cycles 2010-2011 to 2013-2014 } \\
\hline & \multicolumn{1}{c}{ Contrasts } \\
\hline 1 & Urea vs. NBPT-urea \\
2 & Urea at planting vs. NBPT-urea at planting \\
3 & Urea all split vs. NBPT-urea all split \\
4 & Urea split 50 + 100 vs. NBPT-urea split 50+100 \\
5 & Urea split 100 + 50 vs. NBPT-urea split 100 + 50 \\
6 & Urea top-dress vs. NBPT-urea top-dress \\
7 & Urea incorporated vs. NBPT-urea all treatments incorporated \\
8 & Urea incorporated at furrows vs. NBPT-urea incorportaed at furrows \\
9 & Urea incorporated at beds vs. NBPT-urea incorporated at beds \\
10 & At planting vs. all split \\
11 & At planting vs. split 50 + 100 \\
12 & At planting vs. split 100 + 50 \\
13 & Split 50+100 vs. split 100 + 50 \\
14 & Top-dress vs. All incorporated \\
15 & Top-dress vs. incorporated at furrows \\
16 & Top-dress vs. incorporated at beds \\
17 & Incorporated at furrows vs. incorporated at beds \\
\hline
\end{tabular}

\section{Results}

\subsection{Yields}

When analyzing all five cycles together, the interaction cycles $\times$ treatments was significant $(p=0.002)$. However, after excluding the first cycle (2009-2010) from the analysis, this interaction was non-significant $(p=0.051)$. The first cycle performed different from the following ones due to the presence of wheat leaf rust (Puccinia triticina Eriks.) that infected this experiment, due to its closeness to a contiguous experiment where wheat leaf rust had been inoculated for research purposes. Bolton et al. (2008) [20] revised the negative effects on crop production and characteristics of this pathogen. The yields of all five cycles are shown in Table 4. Yields decreased from the cycle 2010-2011 to 2012-2013, with mean yields of 6214,6201 , and $5202 \mathrm{~kg} \mathrm{ha}^{-1}$, respectively; while cycles 2009-2010 and 2013-2014 yielded averages of 6083 and $5149 \mathrm{~kg} \mathrm{ha}^{-1}$, respectively. Within each cycle, there was a highly significant difference among $\mathrm{N}$ treatments $(p<0.0001)$. This was expected due to the inclusion of a control treatment, without $\mathrm{N}$ fertilizer, which yielded an average of $3242 \mathrm{~kg} \mathrm{ha}^{-1}$, while the fertilized treatments yielded an average of $5928 \mathrm{~kg} \mathrm{ha}^{-1}$. In order to avoid redundancy, because yields 
having a direct relationship with $\mathrm{AE}_{\mathrm{N}}$, contrasts for yields are presented in Appendix $\mathrm{A}$ (Table $\mathrm{A} 1$ ) and are addressed while discussing NUE variables. Contrast 1, comparing both urea types was significant $(p=0.026)$ (Table A1), however, the absolute difference in yield was less than $200 \mathrm{~kg} \mathrm{ha}^{-1}$, in favor of urea over NBPT-urea. Contrast 12 , the comparison of all $\mathrm{N}$ applied at planting vs a split application was also significant ( $p=0.023$ ) (Table A1), but the difference in yield was less than $250 \mathrm{~kg} \mathrm{ha}^{-1}$.

\subsection{Grain and Straw N Concentration}

Pooling together all four cycles of available data on grain and straw $\mathrm{N}$ concentration, or any combination of cycles, a significant interaction cycles $\times$ treatments was observed for grain $\mathrm{N}$ concentration and straw $\mathrm{N}$ concentration. Thus, mean grain and straw $\mathrm{N}$ concentrations are presented by individual cycles (Table 4). Although treatments performed differently across cycles in both grain and straw $\mathrm{N}$ concentration, results are shown and contrasts discussed emphasizing the effects of the main comparisons across cycles (contrasts 1, 10 and 14). Grain N concentration was not affected in any of the four cycles by $\mathrm{N}$ sources, but straw $\mathrm{N}$ concentration was affected in the first and last cycles (Table 5), with urea averaging $0.39 \%$ and NBPT-urea $0.37 \%$. N concentration in grain was influenced by timing of application in the first three cycles but not in the fourth cycle. A split application increased grain $\mathrm{N}$ concentration $(1.91 \%)$ compared to one application at planting $(1.83 \%)$. Straw $\mathrm{N}$ concentration was only affected $(p=0.021)$ by timing of fertilizer application in the $2010-2011$ cycle, with $0.45 \%$ y $0.48 \%$ for treatments applied only once at planting and split applications, respectively. Method of fertilizer application was high to highly significant in all four cycles for grain $\mathrm{N}$ concentration. Treatments where the fertilizer was placed below the residue produced a mean $\mathrm{N}$ concentration of $1.89 \%$, compared with $1.73 \%$ recorded for the broadcasting treatment. With the exception of the first cycle (2009-2010), straw $\mathrm{N}$ concentration was also highly influenced by methods of fertilizer application; with incorporated treatments averaging $0.41 \%$, compared with $0.34 \%$ recorded for broadcasting treatments. 
Table 4. Means of wheat yields in five growing cycles (2009-2010 to 2013-2014), and nitrogen concentration in grain and in straw in four cycles (2009-2010 to 2012-2013), as influenced by selected treatments composed of urea sources, timing, and method of fertilizer application at the International Maize and Wheat Improvement Center (CIMMYT), in the Yaqui valley, near Ciudad Obregon, Sonora, Mexico.

\begin{tabular}{|c|c|c|c|c|c|c|c|c|c|c|c|c|c|}
\hline \multirow{2}{*}{ Treatment } & Oct-09 & 2010-2011 & 2011-2012 & 2012-2013 & 2013-2014 & 2009-2010 & 2010-2011 & 2011-2012 & 2012-2013 & 2009-2010 & 2010-2011 & 2011-2012 & 2012-2013 \\
\hline & \multicolumn{5}{|c|}{ Grain Yields $\left(\mathrm{kg} \mathrm{ha}^{-1}\right)$} & \multicolumn{4}{|c|}{ Grain Nitrogen Concentration $(\%)$} & \multicolumn{4}{|c|}{ Straw Nitrogen Concentration (\%) } \\
\hline 1 & 3533 & 4065 & 2895 & 2803 & 2915 & 1.77 & 1.63 & 1.49 & 1.63 & 0.29 & 0.33 & 0.30 & 0.24 \\
\hline 2 & 6299 & 5867 & 5788 & 3912 & 4419 & 1.82 & 1.89 & 1.61 & 1.62 & 0.43 & 0.45 & 0.36 & 0.26 \\
\hline 3 & 6593 & 6860 & 6475 & 5993 & 6057 & 1.93 & 2.08 & 1.74 & 1.84 & 0.55 & 0.52 & 0.39 & 0.35 \\
\hline 4 & 6386 & 6396 & 7293 & 6345 & 6390 & 1.88 & 1.94 & 1.77 & 1.82 & 0.46 & 0.44 & 0.46 & 0.32 \\
\hline 5 & 6345 & 6334 & 6623 & 4622 & 5222 & 1.89 & 1.94 & 1.68 & 1.65 & 0.47 & 0.42 & 0.38 & 0.25 \\
\hline 6 & 6333 & 6687 & 6873 & 6232 & 5204 & 1.95 & 2.12 & 1.87 & 1.88 & 0.48 & 0.52 & 0.43 & 0.38 \\
\hline 7 & 6570 & 6672 & 6192 & 5529 & 5101 & 1.92 & 2.16 & 1.76 & 1.71 & 0.48 & 0.53 & 0.45 & 0.32 \\
\hline 8 & 6291 & 6243 & 6183 & 5656 & 5466 & 1.90 & 2.03 & 1.74 & 1.92 & 0.48 & 0.50 & 0.40 & 0.33 \\
\hline 9 & 5621 & 6311 & 6199 & 5490 & 5621 & 1.87 & 2.02 & 1.67 & 1.72 & 0.43 & 0.45 & 0.40 & 0.30 \\
\hline 10 & 6125 & 5558 & 5423 & 3812 & 3761 & 1.79 & 1.75 & 1.57 & 1.48 & 0.36 & 0.38 & 0.39 & 0.24 \\
\hline 11 & 6462 & 6657 & 6005 & 5445 & 5748 & 1.91 & 2.05 & 1.71 & 1.78 & 0.43 & 0.50 & 0.41 & 0.32 \\
\hline 12 & 6201 & 6119 & 6029 & 5864 & 6086 & 1.82 & 1.96 & 1.69 & 1.81 & 0.41 & 0.39 & 0.42 & 0.31 \\
\hline 13 & 6243 & 5864 & 6103 & 4310 & 4582 & 1.87 & 1.84 & 1.63 & 1.63 & 0.49 & 0.40 & 0.35 & 0.25 \\
\hline 14 & 6556 & 6474 & 6459 & 6077 & 5177 & 2.03 & 2.12 & 1.86 & 1.88 & 0.48 & 0.50 & 0.42 & 0.34 \\
\hline 15 & 5679 & 6458 & 7305 & 4857 & 4800 & 1.81 & 2.09 & 1.81 & 1.60 & 0.41 & 0.51 & 0.44 & 0.28 \\
\hline 16 & 6261 & 6534 & 6770 & 5814 & 5352 & 2.02 & 2.02 & 1.73 & 1.80 & 0.45 & 0.50 & 0.38 & 0.35 \\
\hline 17 & 5907 & 6540 & 6802 & 5667 & 5628 & 1.89 & 2.04 & 2.03 & 1.85 & 0.46 & 0.48 & 0.50 & 0.30 \\
\hline Mean & 6083 & 6214 & 6201 & 5202 & 5149 & 1.90 & 2.01 & 1.75 & 1.76 & 0.45 & 0.47 & 0.41 & 0.31 \\
\hline LSD & 721 & 724 & 992 & 1150 & 942 & 0.14 & 0.12 & 0.20 & 0.14 & 0.10 & 0.08 & 0.07 & 0.05 \\
\hline$n$ & 4 & 4 & 4 & 4 & 4 & 4 & 4 & 4 & 4 & 4 & 4 & 4 & 4 \\
\hline
\end{tabular}


Table 5. $P$ values of contrasts to compare the effects on wheat nitrogen concentration in grain and in straw in four cycles (2009-2010 to 2012-2013), as influenced by selected treatments composed of urea sources, timing, and methods of fertilizer application at the International Maize and Wheat Improvement Center (CIMMYT), in the Yaqui valley, near Ciudad Obregon, Sonora, Mexico.

\begin{tabular}{|c|c|c|c|c|c|c|c|c|}
\hline \multirow{3}{*}{ Contrasts } & \multicolumn{4}{|c|}{$\%$ N Grain } & \multicolumn{4}{|c|}{$\%$ N Straw } \\
\hline & 2009-2010 & $2010-2011$ & 2011-2012 & 2012-2013 & 2009-2010 & $2010-2011$ & 2011-2012 & 2012-2013 \\
\hline & \multicolumn{4}{|c|}{$p$-Values } & \multicolumn{4}{|c|}{$p$-Values } \\
\hline 1 & 0.939 & 0.077 & 0.456 & 0.087 & 0.050 & 0.127 & 0.634 & 0.044 \\
\hline 2 & 0.385 & 0.153 & 0.388 & 0.085 & 0.006 & 0.032 & 0.897 & 0.098 \\
\hline 3 & 0.564 & 0.250 & 0.111 & 0.401 & 0.747 & 0.799 & 0.616 & 0.198 \\
\hline 4 & 0.709 & 0.101 & 0.988 & 0.228 & 0.614 & 0.444 & 0.413 & 0.054 \\
\hline 5 & 0.174 & 0.836 & 0.014 & 0.876 & 0.913 & 0.592 & 0.077 & 0.723 \\
\hline 6 & 0.666 & 0.005 & 0.541 & 0.094 & 0.490 & 0.132 & 0.916 & 0.480 \\
\hline 7 & 0.872 & 0.695 & 0.228 & 0.308 & 0.060 & 0.368 & 0.542 & 0.054 \\
\hline 8 & 0.145 & 0.810 & 0.747 & 0.129 & 0.089 & 0.466 & 0.966 & 0.137 \\
\hline 9 & 0.217 & 0.754 & 0.046 & 0.932 & 0.329 & 0.584 & 0.366 & 0.207 \\
\hline 10 & 0.027 & 0.000 & 0.009 & 0.120 & 0.211 & 0.021 & 0.355 & 0.275 \\
\hline 11 & 0.061 & 0.000 & 0.035 & 0.964 & 0.176 & 0.046 & 0.583 & 0.775 \\
\hline 12 & 0.052 & 0.004 & 0.016 & 0.003 & 0.493 & 0.049 & 0.265 & 0.075 \\
\hline 13 & 0.783 & 0.589 & 0.581 & 0.004 & 0.592 & 0.853 & 0.530 & 0.125 \\
\hline 14 & 0.019 & $<0.0001$ & 0.000 & $<0.0001$ & 0.242 & $<0.0001$ & 0.000 & $<0.0001$ \\
\hline 15 & 0.001 & $<0.0001$ & 0.001 & $<0.0001$ & 0.069 & $<0.0001$ & 0.045 & $<0.0001$ \\
\hline 16 & 0.476 & $<0.0001$ & 0.001 & $<0.0001$ & 0.800 & 0.002 & $<0.0001$ & $<0.0001$ \\
\hline 17 & 0.002 & 0.161 & 0.763 & 0.001 & 0.079 & 0.025 & 0.002 & 0.000 \\
\hline
\end{tabular}

\subsection{Agronomic Efficiency $\left(A E_{N}\right), R E_{N}$, and $P E_{N}$ and Their Relationship with Yield}

\subsubsection{Agronomic Efficiency of Nitrogen $\left(\mathrm{AE}_{\mathrm{N}}\right)$}

The cycles $\times$ treatments interaction for $\mathrm{AE}_{\mathrm{N}}$ was no significant across all four cycles $(p=0.752)$. Means across these cycles are presented (Table 6) and only one set of contrasts was performed (Table 7). $\mathrm{AE}_{\mathrm{N}}$ averaged $19 \mathrm{~kg}_{\text {grain kg}}{ }^{-1} \mathrm{~N}$ (Table 6). The highest $\mathrm{AE}_{\mathrm{N}}$ was recorded for treatments 4 and 3 (with $A E_{N} \geq 21 \mathrm{~kg}$ grain kg${ }^{-1} \mathrm{~N}$ ); while the lowest were treatments 10, 2, and 13 (with $A E_{N} \leq 16 \mathrm{~kg}$ grain $\mathrm{kg}^{-1} \mathrm{~N}$ ). The treatments with the highest $\mathrm{AE}_{\mathrm{N}}$ shared the characteristic of having urea as fertilizer source when this was incorporated. In contrast, the two treatments with the lowest $\mathrm{AE}_{\mathrm{N}}$ shared the characteristics of all the fertilizer being applied at planting and top-dressed. The three treatments with the lowest $\mathrm{AE}_{\mathrm{N}}$ were similar in that all three were top-dress treatments. Sources of urea or timing of fertilizer application did not influenced $\mathrm{AE}_{\mathrm{N}}$ (contrasts 1 and 10), with $p=0.513$ and $p=0.845$, respectively (Table 7). However, methods of application for $\mathrm{AE}_{\mathrm{N}}$ were highly significant $(p<0.0001)$ (contrasts 14 to 16). Top-dress applied treatments recorded an $\mathrm{AE}_{\mathrm{N}}$ of $15 \mathrm{~kg}_{\text {grain }} \mathrm{kg}^{-1} \mathrm{~N}$; while incorporated treatments reached an $\mathrm{AE}_{\mathrm{N}}$ of $20 \mathrm{~kg}$ grain kg-1 $\mathrm{N}$.

\subsubsection{Crop Recovery Efficiency of Applied $N\left(R_{N}\right)$}

A highly significant cycles $\times$ treatments interaction $(p=0.008)$ was recorded when analyzing all four cycles together, or when making all possible combinations of cycles $(p<0.050)$. Thus, means and contrasts were performed for each individual cycle (Tables 6 and 7). In three out of four cycles (except for the last one, 2012-2013), treatments 14, 3, 7, and 6 recorded the highest $R E_{N}$ (with $R E_{N}$ $\geq 0.60 \mathrm{~kg}$ in total aboveground biomass $\mathrm{kg}^{-1} \mathrm{~N}$ ) (Table 6). On the other hand, treatments 10 and 2 recorded the lowest $R E_{N}$ in all four cycles (with $R E_{N} \leq 0.50 \mathrm{~kg}$ in total aboveground biomass kg ${ }^{-1} \mathrm{~N}$ ); with treatment 10 consistently showing the lowest $R E_{N}$. Three out of four of the treatments with the highest $\mathrm{RE}_{\mathrm{N}}(6,7$, and 14) shared the characteristics of having been split applied, $50 \mathrm{~kg}$ of $\mathrm{N}$ at planting $+100 \mathrm{~kg}$ of $\mathrm{N}$ at late tillering, and also similar in that the fertilizer was incorporated (mechanically at planting and through irrigation by late tillering). In contrast, the treatments with the lowest $\operatorname{RE}_{\mathrm{N}}(10$ and 2) were all applied at planting and were top-dress applied. Nitrogen sources never influenced $\operatorname{RE}_{\mathrm{N}}(p>0.050)$ (Table 7). Timing of fertilizer application was highly significant in the two middle 
cycles $(p<0.050)$, but not in the first or last cycles $(p>0.050)$. The mean $\mathrm{RE}_{\mathrm{N}}$ for the two cycles where timing of fertilizer application was significant was $0.50 \mathrm{~kg} \mathrm{~N}$ in total aboveground biomass $\mathrm{kg}^{-1} \mathrm{~N}$, for fertilizer applied at planting and $0.62 \mathrm{~kg} \mathrm{~N}$ in total aboveground biomass $\mathrm{kg}^{-1} \mathrm{~N}$, for split applied treatments. Except for the first cycle, which showed just a trend $(p=0.095)$, for the rest of the cycles, method of fertilizer application was highly significant $(p<0.0001)$ for $\mathrm{RE}_{\mathrm{N}}$; with broadcasting and incorporated methods recording means across all cycles of 0.41 and $0.59 \mathrm{~kg} \mathrm{~N}$ in total aboveground biomass $\mathrm{kg}^{-1} \mathrm{~N}$, respectively.

\subsubsection{Physiological Efficiency of Applied N ( $\left.\mathrm{PE}_{\mathrm{N}}\right)$}

The cycles $\times$ treatments interaction for $\mathrm{PE}_{\mathrm{N}}$ was no significant across all four cycles $(p=0.288)$. Thus, means across all four cycles are presented (Table 6) and the results of only one set of contrasts are presented (Table 7). The most efficient treatments for converting existing $\mathrm{N}$ within the plants into grain $\left(\mathrm{PE}_{\mathrm{N}}\right.$ ) were 10 and 2 (with $P E_{\mathrm{N}} \geq$ to $40 \mathrm{~kg}$ grain $\mathrm{kg}^{-1} \mathrm{~N}$ ); while the treatments with the lowest $P E_{N}$ were 14,6 , and 17 (with $P E_{N} \leq$ to $33 \mathrm{~kg} g r a i n ~ k g^{-1} \mathrm{~N}$ ). The highest $\mathrm{PE}_{\mathrm{N}}$ treatments were similar in that urea treatments were applied top-dress all at planting; while the lowest were similar in that the fertilizer was split applied and incorporated. $\mathrm{PE}_{\mathrm{N}}$ was not influenced by urea sources $(p=0.799)$, but was highly significant for timing and methods of fertilizer application $(p<0.0001$ for both variables) (Table 7). Split application treatments recorded a mean $\mathrm{PE}_{\mathrm{N}}$ of 39 and $35 \mathrm{~kg}$ grain $\mathrm{kg}^{-1}$ $\mathrm{N}$ for incorporated treatments; while top-dress and incorporated methods of application recorded $\mathrm{PE}_{\mathrm{N}}$ of 42 and $35 \mathrm{~kg}_{\text {grain }} \mathrm{kg}^{-1} \mathrm{~N}$, respectively.

Table 6. Means of nitrogen $(\mathrm{N})$ agronomic efficiency $\left(\mathrm{AE}_{\mathrm{N}}\right)$, crop recovery efficiency of applied $\mathrm{N}$ $\left(R E_{N}\right)$, and physiological efficiency of applied $N\left(\mathrm{PE}_{\mathrm{N}}\right)$, as influenced by selected treatments composed of urea sources, timing and method of fertilizer application at the International Maize and Wheat Improvement Center (CIMMYT), in the Yaqui valley, near Ciudad Obregon, Sonora, Mexico.

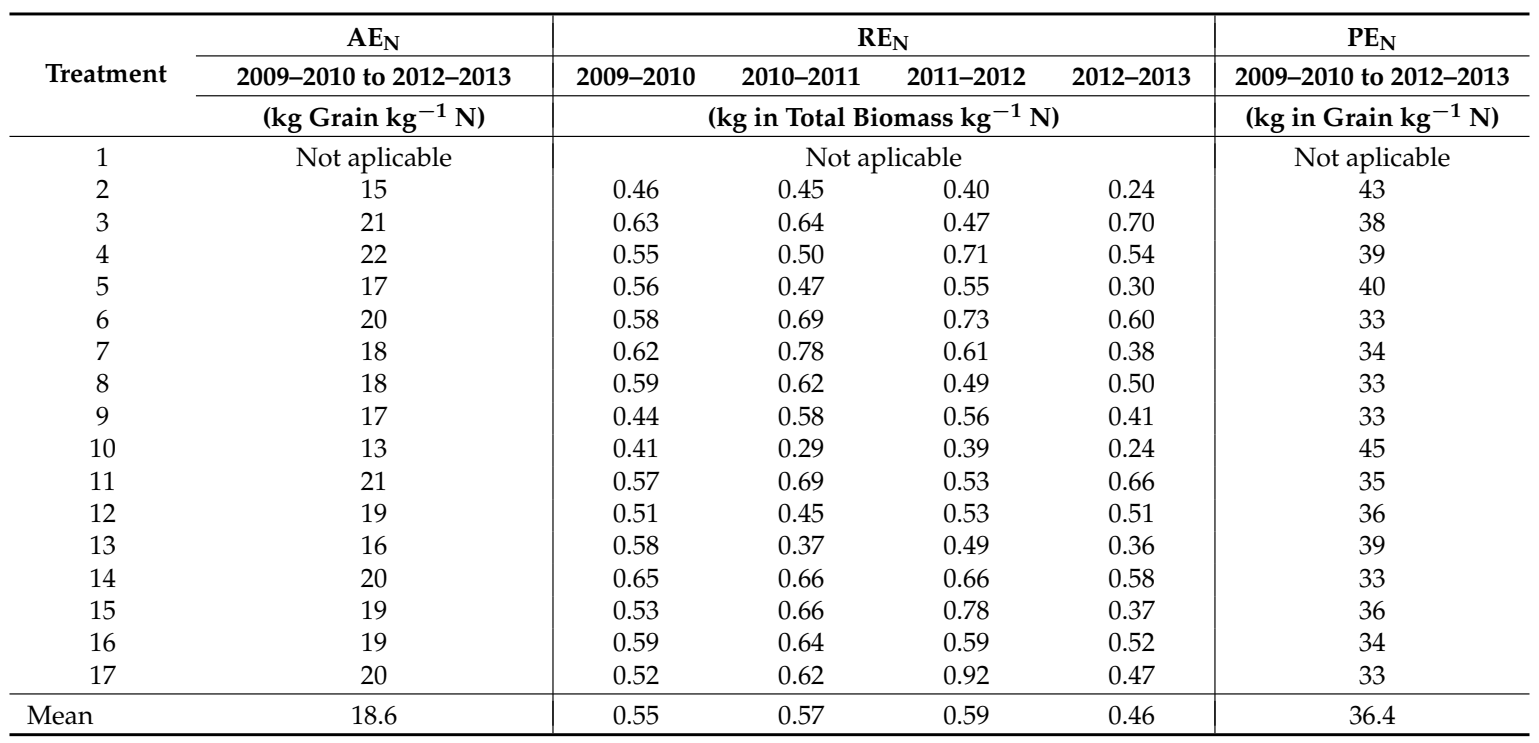


Table 7. $p$ values of contrasts on nitrogen $(\mathrm{N})$ agronomic efficiency $\left(\mathrm{AE}_{\mathrm{N}}\right)$, crop recovery efficiency of applied $\mathrm{N}\left(\mathrm{RE}_{\mathrm{N}}\right)$, and physiological efficiency of applied $\mathrm{N}\left(\mathrm{PE}_{\mathrm{N}}\right)$, as influenced by selected treatments composed of urea sources, timing and method of fertilizer application at the International Maize and Wheat Improvement Center (CIMMYT), in the Yaqui valley, near Ciudad Obregon, Sonora, Mexico.

\begin{tabular}{|c|c|c|c|c|c|c|}
\hline \multirow{3}{*}{ Contrasts } & \multirow{3}{*}{$\begin{array}{c}\text { AE }_{\mathrm{N}} \\
2010-2011 \text { to } 2012-2013 \\
p \text {-Values }\end{array}$} & \multicolumn{4}{|c|}{$\mathrm{RE}_{\mathrm{N}}$} & \multirow{3}{*}{$\begin{array}{c}\mathrm{PE}_{\mathrm{N}} \\
\text { 2010-2011 to 2012-2013 } \\
p \text {-Values }\end{array}$} \\
\hline & & 2010-2011 & 2011-2012 & 2012-2013 & 2013-2014 & \\
\hline & & \multicolumn{4}{|c|}{$p$-Values } & \\
\hline 1 & 0.513 & 0.765 & 0.128 & 0.157 & 0.661 & 0.799 \\
\hline 2 & 0.057 & 0.317 & 0.254 & 0.385 & 0.613 & 0.473 \\
\hline 3 & 0.505 & 0.688 & 0.290 & 0.016 & 0.879 & 0.813 \\
\hline 4 & 0.623 & 0.996 & 0.074 & 0.769 & 0.427 & 0.772 \\
\hline 5 & 0.096 & 0.522 & 0.585 & 0.001 & 0.423 & 0.984 \\
\hline 6 & 0.121 & 0.793 & 0.024 & 0.648 & 0.636 & 0.820 \\
\hline 7 & 0.871 & 0.847 & 0.659 & 0.060 & 0.412 & 0.668 \\
\hline 8 & 0.659 & 0.909 & 0.793 & 0.597 & 0.725 & 0.676 \\
\hline 9 & 0.831 & 0.698 & 0.376 & 0.033 & 0.415 & 0.852 \\
\hline 10 & 0.845 & 0.158 & 0.001 & 0.000 & 0.774 & $<0.0001$ \\
\hline 11 & 0.976 & 0.073 & 0.002 & 0.001 & 0.293 & 0.005 \\
\hline 12 & 0.663 & 0.686 & 0.004 & 0.002 & 0.045 & $<0.0001$ \\
\hline 13 & 0.642 & 0.223 & 0.852 & 0.974 & 0.004 & 0.088 \\
\hline 14 & $<0.0001$ & 0.095 & $<0.0001$ & $<0.0001$ & $<0.0001$ & $<0.0001$ \\
\hline 15 & $<0.0001$ & 0.018 & $<0.0001$ & 0.005 & $<0.0001$ & $<0.0001$ \\
\hline 16 & $<0.0001$ & 0.555 & $<0.0001$ & $<0.0001$ & $<0.0001$ & $<0.0001$ \\
\hline 17 & 0.252 & 0.043 & 0.084 & 0.006 & $<0.0001$ & 0.421 \\
\hline
\end{tabular}

\subsubsection{Correlation and Regression Analyses among Yields, $\mathrm{AE}_{\mathrm{N}}, \mathrm{RE}_{\mathrm{N}}$, and $\mathrm{PE}_{\mathrm{N}}$}

Table 8 shows correlation coefficients between yields and NUE parameters and among NUE parameters, for each individual cycle. Although the magnitude of the correlation coefficients and significance levels varied to a certain degree across cycles, the overall consistency allows making some generalizations. Grain yields and $\mathrm{AE}_{\mathrm{N}}$ showed a positive and highly significant $(p<0.0001)$ correlation, varying from $r=0.50$ to 0.84 . Similarly, yields consistently and significantly $(p<0.0001)$ correlated with $R E_{N}$, ranging from $r=0.60$ to 0.75 . On the other hand, yields were poorly correlated with $P E_{N}$ and the correlations were non-significant $(p>0.050)$, with coefficients varying from $r=-0.24$ to 0.16 . Yields were higher as $A E_{N}$ and $R E_{N}$ increased, but inconsistently related with $P E_{N}$. From nine contrasts that were planned to compare wheat yields (contrasts not shown) in response to the effect of urea sources, three where significantly different $(p<0.050)$ (contrasts 1,2 , and 6$)$. All three comparisons in favor of urea over NBPT-urea, but absolute differences among means were low, averaging only $193 \mathrm{~kg} \mathrm{ha}^{-1}$. Contrasts 10 to 13 were planned to compare timing of applications. Timing of application treatments were designed to test specifically whether applying $\mathrm{N}$ fertilizer all at planting vs split applications would make a difference. Contrast number 10 compared all treatments at planting versus all treatments with split applications and the difference was no significant $(p=0.121)$. Contrasts 14 to 17 were designed to test whether broadcasting (top-dressing) $\mathrm{N}$ fertilizers would make a difference with respect to incorporating the fertilizer into the soil. The overall difference between top-dress treatments and both incorporated treatments (at furrows or at beds) was highly significant $(p<0.0001)$ (contrast 14). The difference between incorporated at furrows versus incorporated at beds was not significant $(p=0.753)$ (contrast 17). 
Table 8. Correlation coefficients between wheat yields and NUE parameters: $A E_{N}, R E_{N}$, and $P E_{N}$ in four cycles, as influenced by selected treatments composed of urea sources, timing and methods of fertilizer application at the International Maize and Wheat Improvement Center (CIMMYT), in the Yaqui valley, near Ciudad Obregon, Sonora, Mexico.

\begin{tabular}{|c|c|c|c|c|}
\hline & Grain Yield & $\mathrm{AE}_{\mathbf{N}}$ & $\mathrm{RE}_{\mathrm{N}}$ & $\mathrm{PE}_{\mathrm{N}}$ \\
\hline \multicolumn{5}{|c|}{ 2009-2010 } \\
\hline Grain Yield & 1 & & & \\
\hline $\mathrm{AE}_{\mathbf{N}}$ & $0.71^{* * *}$ & 1 & & \\
\hline $\mathrm{RE}_{\mathrm{N}}$ & $0.60^{* * *}$ & $0.76^{* * *}$ & 1 & \\
\hline $\mathrm{PE}_{\mathrm{N}}$ & $0.15 \mathrm{~ns}$ & $0.24 \mathrm{~ns}$ & $-0.40^{* * *}$ & 1 \\
\hline \multicolumn{5}{|c|}{$2010-2011$} \\
\hline Grain Yield & 1 & & & \\
\hline $\mathrm{AE}_{\mathrm{N}}$ & $0.65^{* * *}$ & 1 & & \\
\hline $\mathrm{RE}_{\mathrm{N}}$ & $0.68^{* * *}$ & $0.85^{* * *}$ & 1 & \\
\hline $\mathrm{PE}_{\mathrm{N}}$ & $-0.10 \mathrm{~ns}$ & $0.11 \mathrm{~ns}$ & $-0.39 * *$ & 1 \\
\hline \multicolumn{5}{|c|}{ 2011-2012 } \\
\hline Grain yield & 1 & & & \\
\hline$A E_{N}$ & $0.84^{* * *}$ & 1 & & \\
\hline $\mathrm{RE}_{\mathrm{N}}$ & $0.75^{* * *}$ & $0.75^{* * *}$ & 1 & \\
\hline$P E_{N}$ & $0.16 \mathrm{~ns}$ & 0.30 * & $-0.35^{* *}$ & 1 \\
\hline \multicolumn{5}{|c|}{$2012-2013$} \\
\hline Grain yield & 1 & & & \\
\hline $\mathrm{AE}_{\mathrm{N}}$ & $0.50 * * *$ & 1 & & \\
\hline $\mathrm{RE}_{\mathrm{N}}$ & $0.60 * * *$ & $0.93^{* * *}$ & 1 & \\
\hline$P E_{N}$ & $-0.24 \mathrm{~ns}$ & $0.16 \mathrm{~ns}$ & $-0.15 \mathrm{~ns}$ & 1 \\
\hline
\end{tabular}

$\mathrm{AE}_{\mathrm{N}}$ had a positive and highly significant $(p<0.0001)$ correlation with $\mathrm{RE}_{\mathrm{N}}$, ranging from $\mathrm{r}=0.75$ to 0.93 . In contrast, the correlations between $\mathrm{AE}_{\mathrm{N}}$ and $P \mathrm{E}_{\mathrm{N}}$ were much lower and generally non-significant $(p>0.050)$, ranging from $r=0.11$ to 0.30 . The correlations between $R_{N}$ and $P E_{N}$ were negative and, with the exception of the cycle 2012-2013, when this correlation was non-significant $(p>0.050)$, the other three were highly significant $(p<0.01)$, ranging from $r=-0.35$ to -0.40 .

Regression analysis showed that the total variation on $\mathrm{AE}_{\mathrm{N}}$ on each cycle was explained by $\mathrm{RE}_{\mathrm{N}}$ and $P \mathrm{P}_{\mathrm{N}}$, respectively, as follows: $57 \%$ and $36 \%$, explaining a total of $93 \%$ (cycle 2009-2010); $72 \%$ and $24 \%$, explaining a total of $96 \%$ (cycle $2010-2011$ ); $56 \%$ and $35 \%$, explaining a total of $91 \%$ (cycle 2011-2012); and 85\% and 9\%, explaining a total of 94\% (cycle 2012-2013).

\section{Discussion}

In the present study mean $\mathrm{AE}_{\mathrm{N}}$ was $18.6 \mathrm{~kg}_{\text {grain }} \mathrm{kg}^{-1} \mathrm{~N}$, with associated mean yields of $5925 \mathrm{~kg} \mathrm{ha}^{-1}$ (cycles 2009-2010 to 2012-2013). Ayadi et al. (2016) [21] reported a mean yield of $5000 \mathrm{~kg} \mathrm{ha}^{-1}$ for the $150 \mathrm{~kg} \mathrm{~N}^{-1}$ treatment and an associated $\mathrm{AE}_{\mathrm{N}}$ of $13.97 \mathrm{~kg}$ grain kg-1 $\mathrm{N}$; slightly lower yields but substantially lower $\mathrm{N}$ use efficiency, as compared with the results reported in this study. Gupta et al. (2009) [22] found a mean $\mathrm{AE}_{\mathrm{N}}$ for the $150 \mathrm{~kg} \mathrm{~N} \mathrm{ha}^{-1}$ of $16.4 \mathrm{~kg}_{\text {grain kg }}{ }^{-1} \mathrm{~N}$ with a mean yield associated with that treatment of $4545 \mathrm{~kg} \mathrm{ha}^{-1}$, across three growing cycles and two soil types, with comparable $\mathrm{N}$ use efficiency, but lower yields than those recorded in this study. In a study conducted in Arizona, U. S. A., Mon et al. (2016) [23] reported mean $\mathrm{AE}_{\mathrm{N}}$ and associated grain wheat yields during two years (2013 and 2014), for the treatment of $168 \mathrm{~kg} \mathrm{~N}^{-1}$ (their highest yielding treatment), across five irrigation levels, of $17 \mathrm{~kg}_{\text {grain }} \mathrm{kg}^{-1} \mathrm{~N}$ and approximately, $4300 \mathrm{~kg} \mathrm{ha}^{-1}$, respectively (in 2013) and $9 \mathrm{~kg} \mathrm{~N} \mathrm{ha}^{-1}$ and approximately $3400 \mathrm{~kg} \mathrm{ha}^{-1}$, respectively (in 2014). In this same study [23], much lower $\mathrm{AE}_{\mathrm{N}}$ and yield levels were reported as $\mathrm{N}$ rates increased. Duan et al. (2014) [24] reported a robust paper about NUE across four wheat production regions in China over 
a 15 year period and across several fertilizer treatments. They reported a mean $\mathrm{AE}_{\mathrm{N}}$ of $15 \mathrm{~kg}$ grain $\mathrm{kg}^{-1} \mathrm{~N}$, associated with a mean yield of $3300 \mathrm{~kg} \mathrm{ha}^{-1}$.

The point of this discussion is to suggest that, while the NUE parameters recorded in this study were average, the productivity associated to these levels of $\mathrm{N}$ use efficiency is high. Thus, representing a net advance for the overall balance between the need of producing food and the environmental footprint of its production. The $\mathrm{N}$ use efficiency and yield levels in the present study may be associated with; (1) the adoption of long known strategies to increase $\mathrm{N}$ use efficiency, (2) a non-critically limiting $\mathrm{N}$ supply for the crop, provided in part by soil mineralization under a mature conservation agriculture system, and a possible synergy among these two factors. Grahmann et al. (2013) [12] suggested an initial short-term $\mathrm{N}$ immobilization period under conservation agriculture, but steady $\mathrm{N}$ mineralization rates afterward. In support of the hypothesis that wheat in this study grew on a relatively $\mathrm{N}$ rich environment, not only through applied fertilizers, the following evidence is presented.

A soil analysis made before the beginning of the third cycle (2011-2012) showed organic matter concentrations of $0.87 \%, 0.62 \%, 0.40 \%$, and $0.25 \%$ in the $0-15,15-30,30-60$, and $60-90 \mathrm{~cm}$, soil profiles, respectively, with a $\mathrm{pH}$ of 8.8 . Furthermore, in the same experiment station also under conservation agriculture Grahmann et al. (2016) [25] reported organic matter concentrations of $1.2 \%, 0.9 \%, 0.7 \%$, and $0.3 \%$ for soil profiles $0-15,15-40,40-70$, and $70-120 \mathrm{~cm}$, respectively, with a $\mathrm{pH}$ of 8.0. From the organic matter concentrations recorded for this study, it is estimated that around $80 \mathrm{~kg} \mathrm{ha}^{-1}$ of mineral $\mathrm{N}$ could be made available for wheat each cycle in the $0-0.9 \mathrm{~m}$ soil profile. This estimation based on the assumptions of 50\% organic carbon from total organic matter, a $10 \%$ of organic $\mathrm{N}$ from total organic carbon, and $2 \%$ mineralization rate year ${ }^{-1}$ (personal communication from Dr. William Raun, from the Plant and Soil Department, Oklahoma State University). In an early study, comparing conventional tillage versus conservation tillage, Franzluebbers et al. (1995) [26] estimated that, under adequate temperature and moisture conditions, $\mathrm{NO}^{3-}$ accumulated at a rate of $\approx 0.03 \mathrm{~g} \mathrm{~N} \mathrm{~m}^{-2} \mathrm{~d}^{-1}$,

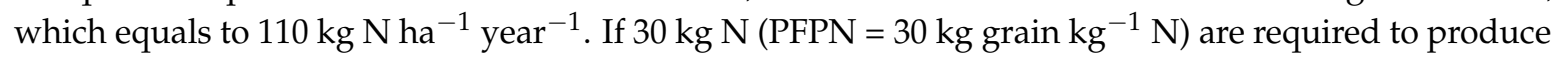
$1000 \mathrm{~kg}$ of wheat grain [27], $80 \mathrm{~kg} \mathrm{~N}$ would support yields of around $2600 \mathrm{~kg} \mathrm{ha}^{-1}$, which is close to the mean yields recorded in the control plots in this study during the last three cycles $\left(2870 \mathrm{~kg} \mathrm{ha}^{-1}\right)$. For the fertilized plots, because mineralization rates would be expected to be higher in fertilized than in the control plots [28], it is estimated that they received a rate of about $230 \mathrm{~kg} \mathrm{~N} \mathrm{ha}^{-1} \mathrm{cycle}^{-1}$ (150 from applied fertilizer +80 from soil mineralization). Thus, if the response of yields to $\mathrm{N}$ fertilization was linear, yields would be around $7600 \mathrm{~kg} \mathrm{ha}^{-1}$, but in reality, this response is well known to increase less as $\mathrm{N}$ availability is increased [23,29]. In addition to mineral $\mathrm{N}$ resulting from $\mathrm{OM}$ mineralization in the present study, another contributing factor could have been related with reduced ammonia losses under CA. Yang et al. (2015) [30] and Sanz-Cobena et al. (2017) [31] reported that when N was applied as a deep band, the ammonia volatilization was lower under CA than under conventional tillage systems and concluded that reduced tillage and crop residues management show a large potential for reducing net greenhouse gas emissions.

Grain $\mathrm{N}$ concentration in the control plots in this study recorded a mean of $1.6 \%$ across the four cycles where this variable was determined. This grain $\mathrm{N}$ concentration, although was the lowest in every cycle (except in the last cycle), compared with the rest of the treatments, was not low, as compared with literature reports. Grahmann et al. (2016) [25] reported mean crude protein concentrations for the control treatment of $2 \%$ to $4 \%$ across four cycles, equivalent to about $0.4 \%$ to $0.7 \% \mathrm{~N}$ concentration $(\mathrm{N} \times 5.70)$, and for the $120 \mathrm{~kg} \mathrm{ha}^{-1}$ treatments, $6 \%$ to $9 \%$ crude protein, equivalent to about $1.1 \%$ to $1.7 \% \mathrm{~N}$ concentrations, comparable to the control treatment $(0 \mathrm{~N})$ in the present study. As an additional argument to support the hypothesis of recording relatively high yields and NUE in this study due to a sufficient (but not excessive) $\mathrm{N}$ supply, $\mathrm{RE}_{\mathrm{N}}$ consistently explained more of the variability of $A E_{N}$ than $\mathrm{PE}_{\mathrm{N}}$, and these findings coincide with literature reports. Moll et al. (1982) [14] suggested that under relatively high $\mathrm{N}$ availability, $\mathrm{N}$ uptake efficiency accounted more than $\mathrm{N}$ utilization efficiency for explaining the variability of $\mathrm{N}$ use efficiency. Similarly, Tian et al. (2016) [32] indicated that $\mathrm{PE}_{\mathrm{N}}$ 
increased during cultivar genetic improvement in China, and that genetic improvement of NUE was mainly related to the increase in $\mathrm{AE}_{\mathrm{N}}$, under relatively high $\mathrm{N}$ supply.

There is a common assumption that wheat (as well as for other crops) yields and quality are irreconcilable objectives $[28,33,34]$, i.e., that one of them has to decrease for the other to increase. This negative relationship was not present in this study, as the highest yielding treatments were also the highest in grain N concentrations, and vice versa. According with Fischer et al. (1993) [35], Grant et al. (1985) [36], and Brown et al. (2005) [37], grain $\mathrm{N}$ decreases when $\mathrm{N}$ fertilizers are applied to a highly yielding responsive environment (low soil $\mathrm{N}$ supply) because yields increase and an increased accumulation of carbohydrates dilutes the $\mathrm{N}$ concentration in grain. On the other hand, the same authors indicate that $\mathrm{N}$ applications to environments with low yielding response probability due to high soil $\mathrm{N}$ supply, would not increase yields but only $\mathrm{N}$ concentration. In the present study, in general, both yields and grain $\mathrm{N}$ concentrations increased or decreased together across all treatments (Figure 2). Averaging the cycles 2010-2011 to 2012-2013, the seven lowest yielding treatments were also the lowest in grain $\mathrm{N}$ concentration, being, from the lowest to the highest, 1 (the control), 10, $2,13,5,9$, and 12. On the other hand, treatment number 6 was the second highest yielding of all treatments with a mean of $6597 \mathrm{~kg} \mathrm{ha}^{-1}$ and also the second with the highest grain $\mathrm{N}$ concentration, with $1.95 \%$. Treatment number 3 was the third highest yielding, with $6442 \mathrm{~kg} \mathrm{ha}^{-1}$ and the fifth highest in grain $\mathrm{N}$ concentration, with $1.90 \%$. One exception to this pattern was observed for treatment number 4, which was the highest yielding treatment of all, with $6678 \mathrm{~kg} \mathrm{ha}^{-1}$ but the ninth in grain $\mathrm{N}$ concentration. This suggests that wheat under this treatment may have promoted conditions for high yields, experiencing a dilution of $\mathrm{N}$ concentration, as high yields imply large carbohydrate accumulation, as has been stated [35-37].

$a$

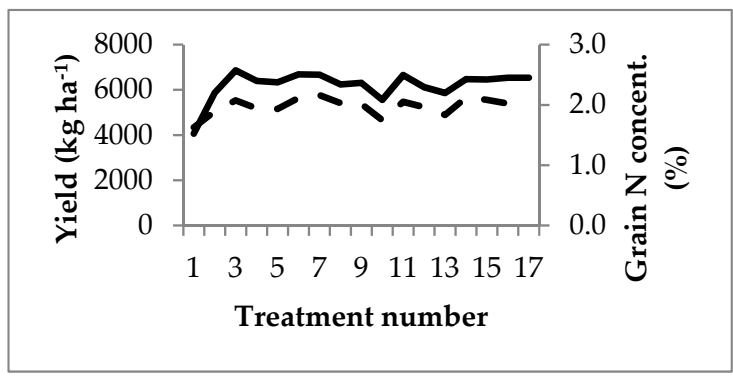

$c$

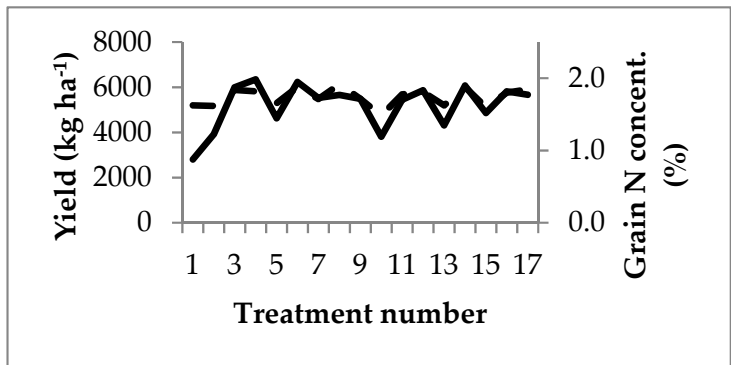

$b$

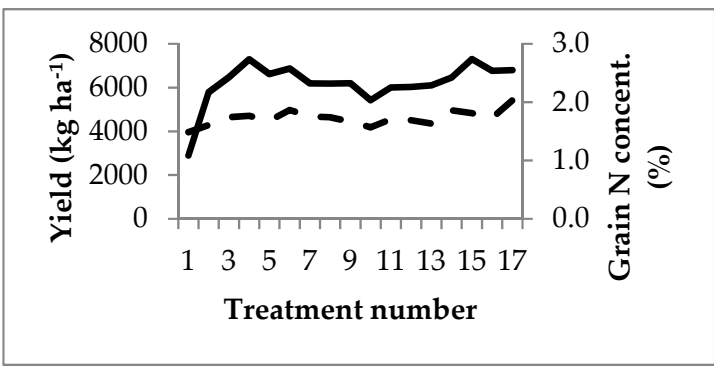

$d$

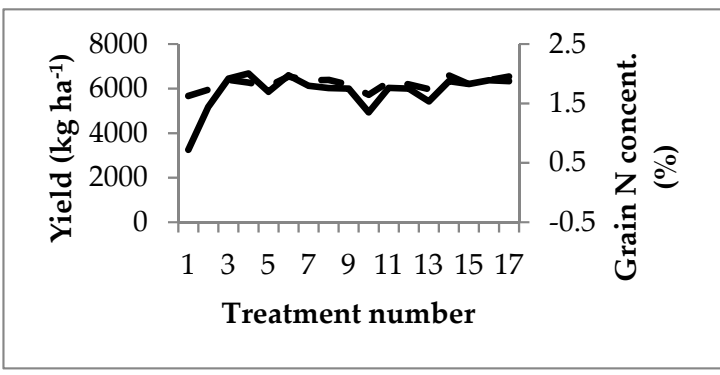

Figure 2. Relationship between wheat yields and grain nitrogen concentrations during the growing cycles of (a) 2010-2011, (b) 2011-2012, (c) 2011-2012, and (d) the average of the three cycles at the International Maize and Wheat Improvement Center (CIMMYT) experimental station, near Ciudad Obregon, Sonora in northwestern Mexico. The Solid lines represent yields and the dashed lines represent grain $\mathrm{N}$ concentration.

\section{Conclusions}

The use of effective fertilizer management practices on a mature conservation agriculture system, under irrigation and under mild temperatures, like in these experiments, allowed relatively high wheat 
yields while recording average or slightly above average $\mathrm{N}$ use efficiency. Apparently, stable, mature conservation agriculture systems seem to provide a buffer capacity against $\mathrm{N}$ fertilizer management practices, due to their stability in releasing mineral N. From the three tested fertilizer management strategies: N sources, timing (or splitting), and methods of fertilizer application were the only factors that realistically showed potential for increasing the profitability for farmers (because of the increases in yields), as well as in environmental terms (because of the increase in $\mathrm{N}$ use efficiency) was method of application. Incorporation of $\mathrm{N}$ fertilizers in conservation agriculture had been identified in past research studies [25], as the most important variable for both wheat productivity and $\mathrm{N}$ use efficiency. From the results of this study, we hypothesize that the combination of CA and smart fertilizer management practices could contribute to increasing food production levels and quality, and, at the same time, improve the degree of sustainability of the current crop production systems. In view of the paramount importance of incorporating $\mathrm{N}$ fertilizers under $\mathrm{CA}$ in this study, future research interests would focus about testing the most effective disk harrow designs for optimum $\mathrm{N}$ fertilizers incorporation.

Author Contributions: I.O.-M. was responsible for finding the funding for conducting the present study. I.O.-M. designed the experiments, supervised the field works and data collection, and was responsible for producing the databases used in the present study. F.N.-R. contributed with reviewing and editing the manuscript and was the responsible for formatting the references as required by this journal (Agronomy). M.E.C.-C. was the foreman in establishing the experiments and on the process of data collection in the field, and helped I.O.-M. in several other ways. C.R.-A. thoroughly reviewed this manuscript and significantly contributed with it. J.S.-C. was the responsible of running the statistical analyses and of writing the full manuscript.

Funding: This research received no external funding.

Acknowledgments: The authors thank the International Maize and Wheat Improvement Center (CIMMYT) and the Mexican Government throughout the Secretaría de Agricultura, Ganadería, Desarrollo Rural, Pesca y Alimentación (SAGARPA) and the Sustainable Modernization of Traditional Agriculture Program (MasAgro) (MasAgro; http:/ / masagro.mx) for financing part of the work presented in this study.

Conflicts of Interest: The authors declare no conflict of interest. The funders had no role in the design of the study, in the collection, analyses, or interpretation of data; in the writing of the manuscript, and in the decision to publish the results.

\section{Appendix A}

Table A1. Orthogonal contrasts to compare the effects of selected treatments composed of urea sources, timing and methods of fertilizer application on wheat yields in four growing cycles (2010-2011 to 2013-2014), at the International Maize and Wheat Improvement Center (CIMMYT), in the Yaqui valley, near Ciudad Obregon, Sonora, Mexico.

\begin{tabular}{clc}
\hline & \multicolumn{1}{c}{ Contrasts } & $p$ Value \\
\hline 1 & Urea vs. NBPT-urea & 0.026 \\
2 & Urea at planting vs. NBPT-urea at planting & 0.002 \\
3 & Urea all split vs. NBPT-urea all split & 0.685 \\
4 & Urea split 50 + 100 vs. NBPT-urea split 50 + 100 & 0.095 \\
5 & Urea split 100 + 50 vs. NBPT-urea split 100 + 50 & 0.160 \\
6 & Urea top-dress vs. NBPT-urea top-dress & 0.015 \\
7 & Urea incorporated vs. NBPT-urea all treatments incorporated & 0.242 \\
8 & Urea incorporated at furrows vs. NBPT-urea incorportaed at furrows & 0.402 \\
9 & Urea incorporated at beds vs. NBPT-urea incorporated at beds & 0.413 \\
10 & At planting vs. all split & 0.121 \\
11 & At planting vs. split 50 + 100 & 0.542 \\
12 & At planting vs. split 100 + 50 & 0.023 \\
13 & Split 50+100 vs. split 100 + 50 & 0.082 \\
14 & Top-dress vs. All incorporated & $<0.0001$ \\
15 & Top-dress vs. incorporated at furrows & $<0.0001$ \\
16 & Top-dress vs. incorporated at beds & $<0.0001$ \\
17 & Incorporated at furrows vs. incorporated at beds & 0.753 \\
\hline
\end{tabular}




\section{References}

1. Gardner, F.P.; Pearce, R.B.; Mitchell, R.L. Physiology of Crop Plants; Scientific Publishers: Jodhpur, India, 2017.

2. Padilla, F.M.; Gallardo, M.; Manzano-Agugliaro, F. Global Trends in Nitrate Leaching Research in the 1960-2017 Period. Sci. Total Environ. 2018, 643, 400-413. [CrossRef] [PubMed]

3. Smith, P.; House, J.I.; Bustamante, M.; Sobocká, J.; Harper, R.; Pan, G.; West, P.C.; Clark, J.M.; Adhya, T.; Rumpel, C. Global Change Pressures on Soils from Land Use and Management. Glob. Chang. Biol. 2016, 22, 1008-1028. [CrossRef] [PubMed]

4. Ercoli, L.; Masoni, A.; Mariotti, M.; Pampana, S.; Pellegrino, E.; Arduini, I. Effect of Preceding Crop on the Agronomic and Economic Performance of Durum Wheat in the Transition from Conventional to Reduced Tillage. Eur. J. Agron. 2017, 82, 125-133. [CrossRef]

5. $\quad$ Rathore, V.S.; Nathawat, N.S.; Bhardwaj, S.; Sasidharan, R.P.; Yadav, B.M.; Kumar, M.; Santra, P.; Yadava, N.D.; Yadav, O.P. Yield, Water and Nitrogen Use Efficiencies of Sprinkler Irrigated Wheat Grown under Different Irrigation and Nitrogen Levels in an Arid Region. Agric. Water Manag. 2017, 187, 232-245. [CrossRef]

6. Pourazari, F.; Vico, G.; Båth, B.; Weih, M. Nitrogen Use Efficiency and Energy Harvest in Wheat, Maize and Grassland Ley Used for Biofuel-Implications for Sustainability. Procedia Environ. Sci. 2015, 29, 22-23. [CrossRef]

7. Meng, Q.; Yue, S.; Hou, P.; Cui, Z.; Chen, X. Improving Yield and Nitrogen Use Efficiency Simultaneously for Maize and Wheat in China: A Review. Pedosphere 2016, 26, 137-147. [CrossRef]

8. Yadav, M.R.; Kumar, R.; Parihar, C.M.; Yadav, R.K.; Jat, S.L.; Ram, H.; Meena, R.K.; Singh, M.; Birbal; Verma, A.P.; et al. Strategies for Improving Nitrogen Use Efficiency: A Review. Agric. Rev. 2017, 38, $29-40$.

9. Raun, W.; Johnson, G. Improving Nitrogen Use Efficiency for Cereal Production. Agron. J. 1999, 91, $357-363$. [CrossRef]

10. Yang, X.; Lu, Y.; Ding, Y.; Yin, X.; Raza, S.; Tong, Y. Optimising Nitrogen Fertilisation: A Key to Improving Nitrogen-Use Efficiency and Minimising Nitrate Leaching Losses in an Intensive Wheat/Maize Rotation (2008-2014). Field Crops Res. 2017, 206, 1-10. [CrossRef]

11. Guttieri, M.J.; Frels, K.; Regassa, T.; Waters, B.M.; Baenziger, P.S. Variation for Nitrogen Use Efficiency Traits in Current and Historical Great Plains Hard Winter Wheat. Euphytica 2017, 213. [CrossRef]

12. Grahmann, K.; Verhulst, N.; Buerkert, A.; Ortiz-Monasterio, I.; Govaerts, B. Nitrogen Use Efficiency and Optimization of Nitrogen Fertilization in Conservation Agriculture. CAB Rev. 2013, 8, 1-19. [CrossRef]

13. Hawkesford, M.J. Genetic Variation in Traits for Nitrogen Use Efficiency in Wheat. J. Exp. Bot. 2017, 68, 2627-2632. [CrossRef] [PubMed]

14. Moll, R.H.; Kamprath, E.J.; Jackson, W.A. Analysis and Interpretation of Factors Which Contribute to Efficiency of Nitrogen Utilization1. Agron. J. 1982, 74, 562-564. [CrossRef]

15. Ortiz-Monasterio, R.; Sayre, K.D.; Rajaram, S.; McMahon, M. Genetic Progress in Wheat Yield and Nitrogen Use Efficiency under Four Nitrogen Rates. Crop Sci. 1997, 37, 898-904. [CrossRef]

16. Rakotoson, T.; Dusserre, J.; Letourmy, P.; Ramonta, I.R.; Cao, T.-V.; Ramanantsoanirina, A.; Roumet, P.; Ahmadi, N.; Raboin, L.-M. Genetic Variability of Nitrogen Use Efficiency in Rainfed Upland Rice. Field Crops Res. 2017, 213, 194-203. [CrossRef]

17. Dobermann, A.R. Nitrogen Use Efficiency-State of the Art. In IFA International Workshop on Enhanced-Efficiency Fertilizers; Agronomy-Faculty Publications: Frankfurt, Germany, 28-30 June 2005; p. 316.

18. Ladha, J.K.; Pathak, H.; Krupnik, T.J.; Six, J.; van Kessel, C. Efficiency of Fertilizer Nitrogen in Cereal Production: Retrospects and Prospects. Adv. Agron. 2005, 87, 85-156. [CrossRef]

19. Malhi, S.S.; Grant, C.A.; Johnston, A.M.; Gill, K.S. Nitrogen Fertilization Management for No-till Cereal Production in the Canadian Great Plains: A Review. Soil Tillage Res. 2001, 60, 101-122. [CrossRef]

20. Bolton, M.D.; Kolmer, J.A.; Garvin, D.F. Wheat Leaf Rust Caused by Puccinia Triticina. Mol. Plant Pathol. 2008, 9, 563-575. [CrossRef]

21. Ayadi, S.; Karmous, C.; Chamekh, Z.; Hammami, Z.; Baraket, M.; Esposito, S.; Rezgui, S.; Trifa, Y. Effects of Nitrogen Rates on Grain Yield and Nitrogen Agronomic Efficiency of Durum Wheat Genotypes under Different Environments. Ann. Appl. Boil. 2016, 168, 264-273. [CrossRef]

22. Gupta, R.K.; Sidhu, H.S. Nitrogen and Residue Management Effects on Agronomic Productivity and Nitrogen Use Efficiency in Rice-Wheat System in Indian Punjab. Nutr. Cycl. Agroecosyst. 2009, 84, 141-154. 
23. Mon, J.; Bronson, K.F.; Hunsaker, D.J.; Thorp, K.R.; White, J.W.; French, A.N. Interactive Effects of Nitrogen Fertilization and Irrigation on Grain Yield, Canopy Temperature, and Nitrogen Use Efficiency in Overhead Sprinkler-Irrigated Durum Wheat. Field Crops Res. 2016, 191, 54-65. [CrossRef]

24. Duan, Y.; Xu, M.; Gao, S.; Yang, X.; Huang, S.; Liu, H.; Wang, B. Nitrogen Use Efficiency in a Wheat-Corn Cropping System from 15 Years of Manure and Fertilizer Applications. Field Crops Res. 2014, 157, 47-56. [CrossRef]

25. Grahmann, K.; Govaerts, B.; Fonteyne, S.; Guzmán, C.; Soto, A.P.G.; Buerkert, A.; Verhulst, N. Nitrogen Fertilizer Placement and Timing Affects Bread Wheat (Triticum aestivum) Quality and Yield in an Irrigated Bed Planting System. Nutr. Cycl. Agroecosyst. 2016, 106, 185-199. [CrossRef]

26. Franzluebbers, A.J.; Hons, F.M.; Zuberer, D.A. Tillage and Crop Effects on Seasonal Soil Carbon and Nitrogen Dynamics. Soil Sci. Soc. Am. J. 1995, 59, 1618-1624. [CrossRef]

27. Li, S.; He, P.; Jin, J. Nitrogen Use Efficiency in Grain Production and the Estimated Nitrogen Input/Output Balance in China Agriculture. J. Sci. Food Agric. 2013, 93, 1191-1197. [CrossRef] [PubMed]

28. Rial-Lovera, K.; Davies, W.P.; Cannon, N.D.; Conway, J.S. Influence of Tillage Systems and Nitrogen Management on Grain Yield, Grain Protein and Nitrogen-Use Efficiency in UK Spring Wheat. J. Agric. Sci. 2016, 154, 1437-1452. [CrossRef]

29. Namvar, A.; Khandan, T. Response of Wheat to Mineral Nitrogen Fertilizer and Biofertilizer (Azotobacter Sp. and Azospirillum sp.) Inoculation under Different Levels of Weed Interference. Ekologija 2013, 59. [CrossRef]

30. Yang, Y.; Zhou, C.; Li, N.; Han, K.; Meng, Y.; Tian, X.; Wang, L. Effects of Conservation Tillage Practices on Ammonia Emissions from Loess Plateau Rain-Fed Winter Wheat Fields. Atmos. Environ. 2015, 104, 59-68. [CrossRef]

31. Sanz-Cobena, A.; Lassaletta, L.; Aguilera, E.; del Prado, A.; Garnier, J.; Billen, G.; Iglesias, A.; Sánchez, B.; Guardia, G.; Abalos, D.; et al. Strategies for Greenhouse Gas Emissions Mitigation in Mediterranean Agriculture: A Review. Agric. Ecosyst. Environ. 2017, 238, 5-24. [CrossRef]

32. Tian, Z.; Li, Y.; Liang, Z.; Guo, H.; Cai, J.; Jiang, D.; Cao, W.; Dai, T. Genetic Improvement of Nitrogen Uptake and Utilization of Winter Wheat in the Yangtze River Basin of China. Field Crops Res. 2016, 196, 251-260. [CrossRef]

33. Taulemesse, F.; Le Gouis, J.; Gouache, D.; Gibon, Y.; Allard, V. Bread Wheat (Triticum Aestivum L.) Grain Protein Concentration Is Related to Early Post-Flowering Nitrate Uptake under Putative Control of Plant Satiety Level. PLoS ONE 2016, 11, e0149668. [CrossRef] [PubMed]

34. Fischer, R.A.; Howe, G.N.; Ibrahim, Z. Irrigated Spring Wheat and Timing and Amount of Nitrogen Fertilizer. I. Grain Yield and Protein Content. Field Crops Res. 1993, 33, 37-56. [CrossRef]

35. Fischer, R.A. Irrigated Spring Wheat and Timing and Amount of Nitrogen Fertilizer. II. Physiology of Grain Yield Response. Field Crops Res. 1993, 33, 57-80. [CrossRef]

36. Grant, C.A.; Stobbe, E.H.; Racz, G.J. The Effect of Fall-Applied N and P Fertilizer and Timing of N Application on Yield and Protein Content of Winter Wheat Grown on Zero-Tilled Land in Manitoba. Can. J. Soil Sci. 1985, 65, 621-628. [CrossRef]

37. Brown, B.; Westcott, M.; Christensen, N.; Pan, B.; Stark, J. Nitrogen Management for Hard Wheat Protein Enhancement. Pac. Northwest Ext. Publ. 2005, 578, 1-14.

(C) 2018 by the authors. Licensee MDPI, Basel, Switzerland. This article is an open access article distributed under the terms and conditions of the Creative Commons Attribution (CC BY) license (http:// creativecommons.org/licenses/by/4.0/). 